\title{
Artigo
}

\section{Brazilian Foreign Policy under President Lula (2003-2010): an overview}

\author{
A Política Externa Brasileira no governo do Presidente Lula \\ (2003-2010): uma visão geral
}

CELSO AMORIM*

Rev. Bras. Polít. Int. 53 (special edition): 214-240 [2010]

\section{Introduction}

As I prepared myself to revise this text, I noticed an article that appeared in today's press (more specifically the French paper "Le Monde") with the following title "Lula's Brazil: an imaginative diplomacy". I read the first sentence: "after seven years of Lula's presidency, Brazil has not much in common with what it was in 2002 "1. I now put the article aside and return to my task.

Brazil's international credibility stems, to a large extent, from the principles that guide her foreign policy. We are a peaceful country, one that abides by international law and respects other countries' sovereign rights. We choose to settle our disputes diplomatically - and we encourage others to act in the same way. We see multilateralism as the primary means of solving conflicts and making decisions internationally. We uphold Brazilian interests with pragmatism, without renouncing our principles and values. These characteristics of our foreign policy have been more or less constant over time. Departures have been rare and short-lived.

Different governments, however, attach varied degrees of importance to specific issues, themes, regions and agendas. Political leaders have given more or less prominence to foreign policy amongst other public policies. International tides often shift direction and new circumstances simply come up unannounced. As Brazil went through structural transformations, her international identity had to be shaped accordingly.

An ever-changing world requires a foreign policy with capacity of adaptation. In a democracy, foreign policy is one amidst a number of public policies. It ought to be subject to the scrutiny of public opinion and be mindful of the people's will

\footnotetext{
* Minister of External Relations of Brazil.

1 Interview with Jean-Jacques Kourliandsky: “Le Brésil de Lula: une diplomatie imaginative”, Le Monde, October 4, 2010.
} 
as expressed at the ballot box. President Lula seized the mandate for change that his two elections granted him in order to shape a new role for Brazil in the world, while remaining faithful to the basic principles that have guided our foreign relations. The author of the newspaper article was right: we did it imaginatively.

\section{A changing world}

The end of the Cold War was followed by a great deal of optimism in the face of a "new world order" some claimed would last forever - or, at least, for a very long period. There were high expectations that the practices of "good governance" - universal patterns to be followed by States in their domestic policies - would in and by themselves guarantee a better life for the unprivileged and the dispossessed.

Globalisation was generally seen as a panacea. Soon, it became clear that globalisation had its downsides. There is strong evidence that it has increased inequalities among and within States. The promise of a better and fairer world that would result from the triumph of "Western" political values (whatever one means by that) and of market economy was not fulfilled. Contrary to Francis Fukuyama's predictions, History did not meet its end.

It is true that the post-Cold War era brought the world closer together. Globalisation produced a higher degree of political interdependence among States. Neglect of international rules of coexistence under the pretext of protecting national security can only occur at a price. Unlawful unilateral actions, particularly after the occupation of Iraq in 2003, are less and less likely to muster support or, even, to succeed.

There was widespread belief that the demise of the Soviet Union would lead to the rise of a single superpower bound to exercise a "benign" hegemony over the entire world. History proved that such a forecast was hasty. There is plenty of evidence that power is in fact being diluted, as a larger number of countries have become stakeholders of global stability. This may not be true when it comes to sheer military might, but it is certainly the case if power is understood in a wider sense: that of influencing behaviour of other actors and, ultimately, the course of events.

The rise of big developing countries - Brazil, China, India, South Africa, Indonesia, Mexico, Egypt, Turkey, among others - is the most important phenomenon of the post-Cold War period. This trend became more evident after the economic meltdown of 2008. The so-called emerging nations enjoy greater political and economic weight in global affairs.

This realignment of forces in the international system is paving the way for a more multipolar order. It has been said that the metaphor that best illustrates how the world is organized today is no longer the "hub-and-spoke", in which all the units must refer to the centre in order to communicate with one another, but rather the "subway map" with its intertangled lines and network of stations, some of which, of course, remain more important than others. 
This tendency to multipolarity has not been followed by the democratisation of multilateral institutions, which suffer from progressive obsolescence. Global governance has been running short of legitimacy, transparency and effectiveness, among other reasons, because developing countries remain underrepresented.

The period that followed the end of the Cold War witnessed greater international cooperation, especially at the UN. It also witnessed global crises related to financial markets; food security; energy; climate change; terrorism; transnational crime. The emergence of a number of influential non-State actors and shifting alliances are also phenomena of our times that make the international arena a far more complex environment.

The fall of the Berlin Wall marked the end of the East-West conflict and ushered in a new era. The rise of developing countries is a structural transformation that is knocking down another wall: the North-South wall. It is a thick wall, albeit an invisible one. It is falling apart much more slowly than the Berlin Wall, but falling it is. In this more multipolar, more complex world in which developing countries are no longer passive bystanders, Brazil is willing to play a greater role.

\section{A new role for Brazil}

The way Brazil is seen - both abroad and within her borders - has dramatically changed in the last few years. The return to democracy, monetary stability, economic growth, poverty reduction, improvement in social indicators, internationalisation of Brazilian companies, the change of status from debtor to creditor, all add up to redefine Brazil's image in the world. In this process, President Lula's magnetic personality, his large experience as a trade union leader, the charisma resulting from an extraordinary life, played a central role. But it is not unreasonable to claim that an audacious and, sometimes, irreverent, foreign policy has contributed to this "leap forward".

In the words of a renowned political commentator: "Twenty years ago, Brazil was struggling to cast off a long legacy of dictatorship, hyperinflation and debt. Today it is a stable democracy with impressive fiscal management, a roaring economy and a wildly popular president. Its foreign policy reflects this confidence and a desire to break free of its older constraints." ${ }^{2}$

Foreign policy is an important instrument for promoting development. The robust trade surpluses sustained over the last few years can be, at least in part, attributed to the opening of new markets. Although Brazilian foreign policy objectives cannot be reduced to a mercantilist view of the world, an active diplomacy, not limited by outdated preconceptions, helped to boost Brazilian business all over the world. Indeed, there was a total upheaval in Brazil's trade patterns: in 2009, non-OECD countries accounted for $57 \%$ of the Brazilian exports. Back in 2002, such figures were far below, amounting to only $38.5 \%$.

2 ZAKARIA, Fareed. Step up to the Plate. Newsweek, September 29, 2010. 
The Brazilian economy felt the impact of the financial crisis of 2008-2009 to a lesser degree than most of the world. Although the expansion of the internal market as well as the countercyclical policies adopted by the Brazilian Government contributed to lessen the impact of the financial crisis, the fact that Brazilian exports no longer hinge primarily on the performance of the rich countries was also a factor in the quick exit from the negative spiral. The diversification of trade partners, with emphasis placed on other developing countries, was part of President Lula's diplomatic strategy from the outset - long before the financial meltdown. Incidentally, it was also the target of harsh criticism, especially in Brazil herself.

Creativity and assertiveness were essential elements in some key foreign-policy decisions that had been taken in the course of the last eight years. From day one, President Lula chose to adopt a clearly independent attitude - fearless, but not reckless - commensurate with Brazil's size and aspirations.

A test case came right after President Lula's inauguration with the US invasion of Iraq. Brazil firmly opposed that move. She did so for a variety of reasons. First, the occupation was not authorized by the UN Security Council, therefore constituting a breach of international law. Second, because we felt that the costs of an armed attack would by far outweigh its hypothetical benefits. Third, because the grounds presented for justifying military action were shaky and ultimately proved to be false. Having presided over three panels on Iraq at the United Nations in the late 1990s, including the very important one on disarmament (which resulted in the replacement of UNSCOM by its successor - UNMOVIC), I had every reason to doubt the allegations about Iraq's possession of weapons of mass destruction. Although we were well-aware of the limited influence Brazil might have on the course of events, President Lula felt it his responsibility to put some diplomatic weight behind Brazil's position: he joined then UN Secretary General Kofi Annan's and Pope John Paul II's efforts to avoid the war.

The fact that our position was based on principles and conviction - and not on a spirit of confrontation - was clearly understood. When President Lula visited Washington in June 2003, President George W. Bush started the meeting with this commentary: "Brazil and the US have their differences, but let's work on what we have in common."

In the international economic front, President Lula faced two immediate challenges: the establishment of the Free Trade Area of the Americas (FTAA) and the conclusion of the Doha Round of the World Trade Organisation (WTO). I will refer to the latter in more detail further ahead.

As far as the FTAA is concerned, President Lula's Administration considered that the terms under which it was being negotiated did not correspond to Brazilian interests. I will not get into specifics here. Suffice it to say that, whereas sensitive issues for Brazil, such as services, investment and government procurement, had already seen a great deal of "progress" (not from our point of view, of course), questions like agricultural subsidies and antidumping, which were dear to us, had 
not been properly addressed and were, in fact, blocked. The new Government was also expected to present its offer in market access in 45 days after the inauguration, which we eventually refused to do. At the very least, the Administration needed more time to assess what was on the table in consultation with the relevant sectors of Brazilian society.

In spite of the difficulties, the parties almost reached a deal at the Miami Conference of November 2003, on the basis of a proposal by Brazil and the US who jointly exercised the presidency of the negotiations. A number of variables interfered and led to the paralysis of the negotiations. Brazil did not oppose the FTAA as a matter of principle, although, with the benefit of hindsight, one would be justified to conclude that the result (or non-result) was not altogether unfavourable to Brazil - especially for her efforts to promote South American integration.

Two aspects of our firm posture vis-à-vis the FTAA negotiations deserve to be retained. First, at the same time as we maintained a constructive negotiating position, we were able to resist the very strong pressure, from within Brazil as well from the outside, to accept an agreement that would run counter our interests. Second, we defended our positions in a pragmatic and mature way.

Brazil-US commercial relations thrived and high level dialogue was always excellent. More important: disagreements on the regional front did not prevent intense cooperation in search of a solution for the Doha Round. This was especially evident in the crucial role both Brazil and the US had in the so-called July Framework (2004).

\section{Global governance}

Brazil is a firm believer in multilateralism. A rules-based international order is indispensable for a more just and democratic world. This is true as much for peace and security as it is for climate change or trade.

The G-20 of the WTO - a group of emerging countries (Brazil, India, Argentina, South Africa and others), which came to include China and at least one LDC, Tanzania - was formed with a view to ensure that the Doha Development Agenda (DDA) would not be another unfulfilled promise and would effectively bring the development dimension into the trade negotiations. More specifically, these countries rebelled against a proposed agreement that would not address the main issues concerning agriculture reform and its impact on international trade.

Agriculture had always been considered as a part of the unfinished business of the Uruguay Round and constituted one of the central aspects of the DDA. At later stages, it came to be recognized not only by Brazil and other developing countries, but also by the US herself, that agriculture was the locomotive (sic) of the Doha Round. Former USTR Robert Portman expressly agreed with me on 
this point, during an informal ministerial meeting sponsored by the OECD in May 2005.

Until that moment, the WTO negotiations followed the same informal procedure that used to be the norm of its predecessor - the GATT. All crucial questions were sorted out by a small group of countries - the Quad, constituted by the US, the European Commission, Japan and Canada. The rebellion of developing countries - by the way, with the support of a number of LDCs and smaller countries - not only prevented a bad result in Cancun, but also led to a new pattern in the decision-making process in the WTO.

Since then, Brazil and India have been meeting with the US and the EU (and, on occasion, with other rich countries, such as Japan and Australia, later joined by China) in the so-called G-4, which eventually replaced the Quad. Most of the progress made from Cancun until the July Package of 2008 was produced in G-4 meetings. The ability of the G-20 to articulate its positions with other group of developing countries was fundamental for progress made during the Hong Kong Ministerial Meeting of December 2005, which decided that the export subsidies for agriculture must be eliminated by 2013 .

It was not the first time developing countries tried to articulate a common position, but, unlike what happened on previous occasions, in which they had essentially a defensive - although justifiable - posture, this time, developing nations were able to advance a constructive agenda based on forward-looking proposals. It was, for example, the G-20 negotiations that became - with adjustments, of course - the architecture for agricultural negotiations.

In Cancun, Brazil was fighting two parallel battles: one was at the negotiating table, against the perpetuation of asymmetries in trade negotiations. Another battle was for winning the "hearts and minds" in a time when the media was selling (or being sold) a totally distorted version, according to which Brazil and her G-20 partners were blocking a deal out of plain obstructionism. Besides, the participation of developing countries (including the poorer ones) gave the whole process more legitimacy.

The change in global governance became all the more evident during the financial crisis. As a response to the turmoil in the markets, which almost brought the world into a depression as severe as that of the thirties, a new G-20 sprung up. It is hard not to relate those two groups which carry the same denomination, even though there is no causal relationship between their respective creations. The fact that the G-20 of the WTO had been successful in enabling developing countries to have a greater say in matters of international trade may have been in the back of the minds of some decision-makers at the time of the consolidation of the Financial G-20 as a high-level forum.

The Financial G-20, thus upgraded, became the leading forum for macroeconomic coordination. It replaced the G-8 (in reality, the G-7, since the presence of Russia in the group had more to do with her nuclear status then with 
her economic weight). When I said, in a conference at the Science-Po in Paris in mid-2009, that the G-8 was dead, this was seen by many, especially in Brazil, as a manifestation of hubris. Soon after that, the Pittsburgh Summit confirmed the G-20 as the premier forum for economic and financial matters.

Brazil has also been a fundamental player in the negotiations concerning the most critical matter of our time: climate change. Brazil is firmly attached to the principle of "common but differentiated responsibilities", which takes into account the rich countries' historic share in global warming and recognizes the right of poor countries to develop. Nevertheless, we made an ambitious offer of emission cuts at the $15^{\text {th }}$ Conference of the Parties in Copenhagen, in December 2009, which actually helped push others, especially among the so-called "emerging nations", to do the same. With her bold proposal, and unlike other countries, including some of the rich ones, Brazil chose not to hide behind other countries' reluctance. At the same time, we did not allow anyone to hide behind Brazil. In a situation in which the survival of mankind was at stake we decided to preach by example.

Unfortunately, the Copenhagen Summit did not reach a consensus. The feasible alternative was the so-called "Accord". Although circa thirty countries were included in the discussions, the crucial negotiation of the Accord was to take place between US President Barack Obama, on one side, and the leaders of the "BASIC" group - President Lula of Brazil, President Jacob Zuma of South Africa, Prime Minister Manmohan Singh of India and Prime Minister Wen Jia-Bao of China - on the other. This again points to the changes in global governance already underway. In the event, all this effort came to naught, partly because the Accord was in itself insufficient (on finance and on reduction commitments by some countries, most notably the US), partly because the method to conduct the meeting left some countries excluded and justifiably resentful.

On another theme more directly related to the survival of mankind, i.e., disarmament and non-proliferation, Brazil has renewed her engagement with the struggle for the total elimination of nuclear weapons. Brazil chaired the 2005 Review Conference of the Nuclear Non-Proliferation Treaty and gave a strong push for the positive outcome of the 2010 Review Conference, which reaffirmed the "thirteen steps to disarmament", adopted in 2000, but which had fallen into oblivion. These steps were based on the proposals made by the New Agenda Coalition, a group composed by developed and developing countries of different regions, committed to a world free of nuclear weapons.

The economic crisis of 2008-9 sparked the reformist momentum the world is going through. However, if the redesign of economic architecture is underway, the political institutions remain regrettably obsolete and, thus, unable to properly handle the pressing issues of our times. 
The United Nations needs to be urgently reformed in order to preserve its legitimacy and effectiveness. When the UN was founded, it reflected the realities that emerged from the World War II. Since then, the Cold War has come and gone and the wave of Afro-Asian decolonisation has long come to a conclusion, to mention just two salient features of the second half of the $20^{\text {th }}$ century. In parallel, UN membership was expanded from some 50 countries to almost 200 without significant changes in the Organization's only body, at least in theory, with ability to enforce decisions: the Security Council. As David Rothkopf, of the Foreign Policy magazine, noted:

"The United Nations is weak by design, conceived for a world in which the U.S. and other major powers preferred to leave the real options for action to themselves. (...) The organisation is long overdue for structural reform, and while revamping the list of who sits on the U.N. Security Council is an important part of it (the organisation has no claim on legitimacy with France and Britain being permanent members and India and Brazil left on the margins), the real changes required involve empowering the organization, and not only to reach binding decisions on transnational issues, but to actually be able to enforce them. (...) Nothing guarantees the organization's ineffectiveness as surely as burdening it with a structure that captures in amber the post World War II power structure of the world."3

It is almost a truism to state that the United Nations Security Council membership should reflect the current distribution of world power. The role of developing countries in preserving international peace and security must be recognized with an eye to the future rather than to the past.

It is inadmissible that the developing world, which accounts for the bulk of UN membership, is not adequately represented among the permanent members. Brazil, along with India, Germany and Japan, assembled in the G-4, has been campaigning for a reform that includes new permanent and non-permanent members. Reforming the UNSC is not a simple matter, but it is an indispensable task. In spite of the complexities involved in changing the UN Charter (such as the need for a wide majority in the General Assembly and the convergence of the present permanent members in the ratification process), we are convinced that the reformist momentum, which started in the economic sphere, will eventually extend to the area of peace and security. World leaders whose countries would not directly benefit from the reform - French President Nicholas Sarkozy, Portuguese Prime Minister José Socrates and British Deputy Prime Minister Nick Clegg, among many others - have already expressed clearly their support for the expansion of the Security Council.

3 ROTHKOPF, David. UNGA week, either you are in or you are out (probably out). Foreign Policy, September 20, 2010. 
Brazil is fully engaged in the G-4 initiative, which we believe gained momentum at the $65^{\text {th }}$ General Assembly and will benefit from the presence of three out of four of its members in the Security Council in 2011. The fact that South Africa, which does not formally belong to the G-4, but shares most of its ideas, will integrate the Council will reinforce this momentum. Actually, one might even say that, taking into account that another important African country, i.e. Nigeria, as well as Brazil, will continue to be a member, the composition of the 2011 UNSC will resemble very much to what an expanded Council should look like.

Contrary to the ill-advised opinion of many critics of Brazilian foreign policy, however, all actions undertaken by Brazilian diplomacy have not been conditioned by the supposedly central aim of becoming a permanent member of the Security Council. In fact, Brazil has shown that she will not comply with any course of action, with which she does not agree, just to please this or that influential power in order to secure a permanent seat. Having being elected to the Council for the 20102011 term, Brazil took the responsibility the international community entrusted her with very seriously - as it has been done on the nine previous occasions Brazil served as a non-permanent member ${ }^{4}$. That responsibility is to contribute primarily to peace and security rather than to serve her own parochial interests.

This way of thinking inspired the initiative we took, together with Turkey, to find a solution to the vexing question of the Iranian nuclear programme. As a result of an intense diplomatic negotiation carried out by those two countries with Iran, the Tehran Declaration of May 17, 2010 - a day future History books will register, according to an editorial of "Le Monde" - laid out the terms for a swap of Iranian low enriched uranium for nuclear fuel for the Tehran Research Reactor (TRR).

The objective of these negotiations, which picked up from the terms proposed by the Vienna Group (France, Russia and the US, endorsed by the Atomic Agency) in October 2009, but which had been first accepted and then rejected by the Iranian Government, was, above all, to build confidence between Iran and the international community regarding its nuclear programme. Iran had refused the proposal on three grounds: i) the quantity of uranium to be swapped; ii) the venue of the swap; and iii) the timing for delivering low enriched uranium and that for receiving the nuclear fuel, which, according to Iran, had to coincide (the idea of "simultaneity").

This is neither the time nor the place to get into specifics. The press has already given a broad repercussion, often criticising, sometimes praising our efforts. Let me just say that a few weeks prior to the Declaration of Tehran, my interlocutors in Tehran - including my colleague, Minister Manouchehr Mottaki

4 Along with Japan, Brazil is the member State that has been elected to a non-permanent seat at the UNSC the most times. 
- were still insisting that the quantity of uranium to be given away should be limited to 1,000 kilos (other important personalities, including in the opposition, felt that the equivalent in nuclear fuel to 1,200 kilos would be beyond the needs of the TRR); the exchange should take place on Iranian territory (according to their argument, doing otherwise would alienate Iranian sovereignty); the swap should be simultaneous (the Iranian low enriched uranium should only leave Iran when the fuel arrived).

During the course of the negotiations, the three issues were solved: i) Iran agreed to exchange 1,200 kilos of low enriched uranium for 120 kilos of fuel; ii) Iran accepted that the exchange would take place on the territory of a neutral power - in this case, in Turkey, and iii) Iran agreed on transferring her low enriched uranium right away, even if the nuclear fuel would not come before one-year's time. Additionally, Iran agreed to send a letter to the International Atomic Energy Agency (IAEA) formally committing to the terms of the swap.

Why did Brazil and Turkey succeed where the traditional powers had failed? First, because Brazil and Turkey - both developing countries - have good relations with Iran. Brazil is a member of the G-15, a group of developing countries to which the Iranian Government attaches a great deal of importance, having presided over its last conference. Turkey not only is located in the Middle East, but is also an Islamic nation, and, under the present AKP Government, has had a very active and independent foreign policy, which naturally facilitates dialogue. Second, Brazil and Turkey are non-nuclear States, thus enjoying far greater legitimacy before the eyes of the Iranian authorities as far as efforts directed at non-proliferation are concerned. Third, they did not assume upfront that the Iranian nuclear programme had necessarily non-peaceful uses. Both believed, much as the original proponents and the IAEA itself did, that the swap deal would help dispel at least some doubts. Finally, Brazil and Turkey have always recognized Iran's right to a peaceful nuclear programme, including the right to enrich uranium, so long as the IAEA could send its inspectors in and ensure the applicable regulations were being respected.

Brazil and Turkey had it always clear that the Tehran Declaration did not solve all questions regarding the Iranian nuclear programme. Important issues such as $20 \%$ enrichment and the quantity of uranium in Iran's possession would certainly be part of future discussions, once confidence was recreated (or simply created).

The swap agreement was a gateway for a broader negotiation regarding Iran's nuclear programme. In the course of negotiations, which extended for 18 hours on May 16 and followed months of intense consultations, Iran made voluntary, but difficult, concessions in order to allow the deal to be accepted by all concerned. Surprisingly, the Western powers rushed to announce that a new round of sanctions would still be pursued, irrespective of the results achieved by President Lula and Turkish Prime Minister Recep Tayyip Erdo an. Eventually, new sanctions were imposed against Iran by the Security Council on the very day 
the so-called Vienna Group submitted its comments on the Tehran Declaration to the IAEA, allowing no time for Iran to reply.

Why did the Western powers show this attitude of disregard toward the Tehran Declaration? First, it seems that they were expecting a negative result from the Brazilian-Turkish efforts, which they thought would prove them right about Iran's intentions. Second, there was probably a change of heart in some of the Western powers along this process. In spite of President Obama's letter to President Lula (sent about three weeks before the latter's visit to Tehran), which reaffirmed the points considered essential for an agreement - all of which would appear in the Declaration of May 17 - the US and her allies opted for a course of action which relied on increased sanctions. Having obtained the endorsement of the two more sceptical countries within the P-5 (China and Russia), the proponents of this "harder line" did not want to miss this "window of opportunity", lest this somewhat fragile consensus among the P-5 might disappear. Lastly, as some critics have argued, some of the P-5 may not have liked to see two emerging nations like Brazil and Turkey playing a pivotal role in a crucial question concerning peace and security in the Middle East, especially in one where they themselves had failed. Former IAEA Director-General Mohammed El-Baradei put it well: "it seems that they could not take yes for an answer"s.

On June 9, Brazil and Turkey voted against the sanctions in the Security Council. This was the first time ever that Brazil voted against a resolution that was approved. Having come with a solution - based on a scheme which was not of our making and which required arduous bona-fide negotiations with Iran - we could not do otherwise.

Brazil still believes that diplomacy can prevail. In a recent meeting on the margins of the UNGA, the P- $5+1$ stated that they are ready to engage with Iran again and that they "welcome a meeting of the Vienna Group on the technical implementation of a revised arrangement for the supply of fuel to the TRR." It is hard to imagine that any new discussions will not take the Tehran Declaration into consideration.

The so-called fourth round of sanctions against Iran was authorized in an atmosphere of bargaining and secrecy totally incompatible with the role the Security Council should play, making it clear for the entire world that reform should go beyond the question of composition: the methods of work of the Council need to be made more transparent and accountable to the entire international community.

In a way, there is a parallel between the Iranian episode and Cancun: on both occasions, Brazil tried to find constructive and pragmatic solutions for real problems affecting the international community (although in Cancun our own

5 Interview to "Jornal do Brasil" on May 30, 2010.

6 Communiqué of the P-5+1 meeting of September 22, 2010. 
material interests were at stake). On both occasions, those moves were seen as sheer obstruction or dangerous deviation from the pre-established path. After Cancun, it took five months or so for our position to be fully understood by some of our partners. But it was this understanding that allowed negotiations in the WTO to be resumed, leading eventually to the July Framework. Let us wait and see if our efforts, which resulted in the Tehran Declaration will be properly appreciated. And, if so, how long it will take for this to happen.

\section{Solidarity}

The exercise of solidarity with those who are more in need has been one of the tenets of President Lula's foreign policy. The Brazilian Government has not been indifferent to the necessities of countries stricken by poverty, armed conflict and natural disasters.

Such attitude of non-indifference is not contradictory with the defence of our own interests. We are convinced that in the long run an attitude based on a sense of humanity that favours the promotion of development of the poorest and most vulnerable will not only be good to peace and prosperity around the world. It will bring benefits to Brazil herself, in political as well as economic terms. This dialectic relation between national interest and the exercise of solidarity has been a fundamental aspect of President Lula's foreign policy.

In the last eight years, Brazil has substantially increased her humanitarian assistance. In 2010 alone, emergency funds were donated (mostly through International Organizations such as the UNDP, the UNHCR and the WFP) to 36 countries facing hardship. Brazil has also vigorously promoted South-South cooperation, sometimes in association with international bodies like the World Bank and the ILO. Brazil's Cooperation Agency (ABC) - a branch of the Foreign Ministry - keeps projects in many countries in Africa, Latin America and the Caribbean and in Asia. In 2009 alone, 414 technical cooperation projects were carried out. In early 2004, President Lula championed, along with Spanish Prime-Minister José Luis Zapatero, former French President Jacques Chirac and former UN Secretary-General Kofi Annan the Global Action Against Hunger and Poverty. One of the most visible results of such pioneer initiative was the creation of UNITAID, whose purpose is to facilitate access to treatment for HIV/AIDS, malaria and tuberculosis, especially in Africa.

Since 2004, Brazil has had the responsibility of leading the military component of the United Nations Mission in Haiti (MINUSTAH), committing herself to the stabilisation of the Caribbean country after a period of turmoil and political instability. At the same time as our military achieved the demobilisation of armed gangs, bringing peace to Port-au-Prince shantytowns, the Brazilian Government has been carrying out a series of civilian activities aimed at tackling problems related to poverty, infrastructure and development. In addition to the 
activities of our military engineers stationed in Haiti, a great number of projects of technical cooperation were set in motion. Along with the other IBSA Fund partners (India and South Africa), Brazil has financed a solid residues recycling plant in Port-au-Prince, which creates jobs and helps clean the environment. This "cash for work" project was considered a model of South-South cooperation by the United Nations Development Programme, from which it earned two special prizes, including one in the context of the Millennium Development Goals.

When a devastating earthquake struck Haiti on January 12 - dragging more than 200,000 lives with it, including 20 of our own countrymen - Brazil responded quickly to the new challenges, with direct help and intense participation in broader international efforts. In total, Brazil committed US \$350 million, divided roughly in equal parts between actions of humanitarian relief and reconstruction projects. Unlike what happened in the case of other donors, much of our promised aid was already disbursed and a great part of what remains to be given out is waiting for decisions to be made by Haiti or in international fora. Our response also included the doubling of our military personnel, which now surpasses 2,000 troops.

Upon taking office in 2003, President Lula played a leading role in the creation of the Group of Friends of Venezuela, which helped avoid that the critical situation in that neighbouring and friendly nation deteriorated into some form of violent civil conflict. The Group - integrated by Brazil, Chile, Mexico, Portugal, Spain and the US - was instrumental in assuring some measure of dialogue between President Chávez and the opposition. This culminated with the realisation of the so-called "Recall Referendum" in conditions generally considered as free and fair by the international community.

A number of other examples relating to our neighbours and other countries beyond our region illustrate how a policy based on non-intervention can also display a high degree of "non-indifference".

\section{Universalism}

During President Lula's Government, the network of our bilateral relations expanded considerably. In 2002, Brazil had 150 postings overseas. That number is now at $230^{7}$. The new postings included 52 embassies, 6 missions to International Organizations, 22 consulates and one diplomatic office, in Palestine. Among them are 23 in Africa, 15 in Latin America and the Caribbean, 13 in Asia and 6 in the Middle East.

This increase in postings abroad was followed by the expansion of the corps of diplomatic personnel. In 2005, Brazil had grossly 1.000 diplomats in the service. Today that number is at 1,400 . This expansion - compatible with the universal nature of our foreign policy - is likely to go on, as Brazil's role in international affairs keeps growing.

7 Number of postings already functioning or in the process of being opened. 
High-level visits, especially presidential ones, are also an indicator of a country's willingness and ability to strengthen her contacts abroad. Since his inauguration, President Lula paid as many as 259 visits to 83 foreign countries, including international meetings. As Foreign Minister I travelled overseas 467 times, having been received in 101 countries at least once. Presidents, Prime Ministers, Kings, Queens, Ministers, Vice-Ministers and high officials of 137 nations and several leaders of International Organizations made official trips to Brazil since 2003, amounting to an impressive record of 904 visits $^{8}$.

Brazil pursues dialogue with countries of all regions, creeds, colours and backgrounds. No country can afford to relate only with those with whom she agrees or with whom the affinities are self-evident. Of course, it is natural that closer relations will occur when there are commonalities of views and shared interests, whether dictated by geographical proximity, history or prospects of commerce with mutual advantage. The politics of isolation (self-isolation as well as isolation from others), however, is almost always counterproductive. It does not serve the purposes of peace and stability in the world, since governments that feel themselves mistreated in this way become even more self-righteous and tend to radicalize their positions. Many, either as a pretext or out of genuine fear, tend to treat opponents among their own nationals as tools of foreign powers.

\section{South America}

South American integration is Brazilian foreign policy's top priority. Brazil recognizes that she is stronger and more influential in global affairs by working closely with her neighbours and by helping promote peace and prosperity in her region. In spite of her continental dimensions and vast natural resources, Brazil made a resolute choice to work for regional (i.e. South American) integration. Closer economic and political relations contribute to growth and stability. It also increases our (Brazil's and South America's) clout in global negotiations.

Mercosul is the original cell of South American integration. Although its original motivation was fundamentally political (and notably so in the first phase of Brazil-Argentina rapprochement), the bloc formed by Brazil, Argentina, Paraguay and Uruguay started out as a free trade agreement and a (however imperfect) customs union. In spite of all shortcomings, the numbers are eloquent: under President Lula alone, Brazilian trade with our Mercosul partners rose from US\$ 8.8 billion in 2002 to US\$ 36.6 billion in $2008^{9}$. Recently, Mercosul's share of Brazilian foreign trade overtook that of the United States.

Economic and productive chains of Brazil, Argentina, Paraguay and Uruguay are far more integrated now than at any other moment in History. Pioneering

8 Until August 25, 2010.

9 In 2009, an atypical year in face of the financial crisis, the number sunk to US\$29 billion. In 2010 the figures are already soaring: US $\$ 20.7$ billion between January and July. 
experiments are being put together in development financing and monetary matters. Local currencies are being used for some transactions, thus reducing the cost of regional trade for small and medium enterprises. The upcoming accession of Venezuela will strengthen the bloc, increasing its energy resources and allowing the Southern Cone of Latin America to be linked to the Caribbean Sea.

Some other important achievements were obtained during the past eight years. Part of the credit has to go to President Lula's strong determination to push for integration, even in the face of bitter criticism. Very often, the Government had to impose its view over the objection of groups and sectors incapable of seeing the long-term interest - not only of the country as a whole, but their own. This was the case in the treatment of asymmetries within the bloc (involving mainly the smaller partners, Uruguay and Paraguay), but also in our relations with Argentina, whose economy was just emerging from a profound crisis and had undergone a period of drastic de-industrialization. There was often the need to show flexibility and, in some cases, even tolerance. It would be unreasonable and probably unfair to expect such an attitude to come spontaneously from the business class, even if - at the same time - our exports to Argentina were growing and our investments were multiplying. In these situations, government has to take the lead, and that is what we did. The result, as shown in the figures quoted above, were more than positive: not only did Mercosul as a whole become a larger trading partner for Brazil than the US, but Argentina alone absorbed more Brazilian exports than any other country, except China, in the last few months - a tendency very likely to be maintained.

Mercosul is not merely a trade association. In 1998, the bloc had acquired a strong political dimension with the Protocol of Ushuaia, which condemns any attempt to overthrow a democratically-elected government. Since 2007, Mercosul's Parliament has been functioning in Montevideo. As I write this article, ahead of the next December's Summit, in Foz do Iguaçu, the rules for national representation - which balance some degree of proportionality to demographic weight with the principle of sovereign equality - were just agreed by Mercosul's Council of Ministers. This will make it possible that, not very far in the future, Mercosul's congressmen will be elected directly by popular vote, as mandated by the Treaty that instituted the Parliament.

Mercosul's Fund of Structural Convergence (FOCEM), established in 2005, is another example of our firm commitment to a balanced development for the benefit of the peoples of all member States. Inspired by similar experiences in Europe, the FOCEM has been utilised to finance development projects, such as housing for the poor in Paraguay; lines for transmission of electricity in Paraguay, Uruguay and Argentina; and a Latin American University library in a town in Brazil that borders both Argentina and Paraguay. A plurinational strategy to combat foot-and-mouth disease (which also includes Bolivia, an associate member) is another example of how the Fund has been used to promote socioeconomic 
development. Brazil is the main contributor to the fund providing circa $70 \%$ of its total resources.

The establishment of a free trade agreement between Mercosul and the Andean Community in 2004 virtually erected a South American free trade zone - an idea I tried to advance for the first time when I was President Itamar Franco's Foreign Minister (1993-1994). President Fernando Henrique Cardoso had the indisputable merit of inviting South American Heads of State and Government for a first summit of this kind in 2000. But it was during President Lula's term that a concentrated effort was made to achieve that objective.

The integration of South America involved not only innumerable rounds of negotiation by Ministers and/or high-level officials, but also the personal participation of the President himself. In a little more than eight months in office, President Lula had received, at least once, every South American Head of State. In two years, he visited all countries of the region. Needless to say: nothing remotely similar had happened before. At the same time as advances were made in the commercial area, a renewed push was given on infrastructure projects. As a result, the big industrial and agricultural centres in the Atlantic Coast and its hinterland will be linked, for the first time, to the Pacific ports (and vice-versa), a feat that North America accomplished in the $19^{\text {th }}$ century.

This second level of regional integration has a clear political dimension. All South American nations are now gathered under the same institutional umbrella. The Union of South American Nations (Unasul) was officially founded in Brasilia in 2008 with the signing of a constitutive treaty. But the first important step toward political integration dates back to 2004, when a Presidential Summit in Cuzco, Peru, decided to create the South American Community of Nations $(\mathrm{CASA})^{10}$ - Unasul's original name.

Several thematic commissions were established under Unasul, among them the Councils of Health, Infrastructure, Drug Control and Defence. Besides the cooperation dimension, Unasul has proven useful to resolve crises the countries of South America had to face collectively. In 2008, as the political situation in Bolivia deteriorated, Unasul offered its good offices, which proved instrumental in the reconciliation process. More recently, rising tensions between Colombia and Venezuela were eased with the assistance, among others, of Unasul SecretaryGeneral, late Argentinean President Nestor Kirchner, who joined in the mediation efforts. When a police rebellion threatened the institutional stability in Ecuador, Unasul acted promptly not only to condemn the attempted coup, but also to avoid its dire consequences.

While the usual critics decried that Unasul suffered from congenital antiAmericanism, it is becoming ever more evident that the regional organisation has an important role in resolving - or at least addressing conflicts in the region (the polemics around US bases in Colombia was another example). Unasul has

10 The acronym is the same word for "house" or "home" in both Portuguese and Spanish. 
also given South America a face. It was a motive for pride for anyone who was present to watch the Chilean President Michelle Bachelet address the $2^{\text {nd }}$ South American-Arab Countries' Summit in Doha, Qatar, in 2009, on behalf of the whole of South America. If any further evidence was needed to show the usefulness of Unasul as an instrument for dialogue, the fact that President Obama asked for a meeting with Unasul during the $5^{\text {th }}$ Summit of the Americas, held in Port of Spain, could be another illustration.

The consolidation of South America as a political actor is an important step toward the broader integration of Latin America and the Caribbean. In December 2008, President Lula convened a "multisummit" in Costa do Sauípe, in the state of Bahia. The gathering included a Mercosul Summit, a Unasul Summit, a Rio Group ${ }^{11}$ Summit, and, finally, a Summit of all 34 Latin American and Caribbean States - the first ever to take place in 200 hundred years of independent life of most countries. Indeed, the "CALC" (the acronym by which it became known) was the first occasion on which the Heads of State and Government of Latin America and Caribbean nations met without the sponsorship or tutelage of Europe or North America.

Consolidating the integrationist drive, a second edition of CALC was organized in Cancun in February 2010. The most important decision taken in Mexico was to institute the Latin American and Caribbean OrganisationCELAC, in the Portuguese/Spanish acronym. Another Latin American and Caribbean Summit is already expected to take place in Venezuela, in 2011. At that meeting, CELAC's institutional architecture is expected to be defined.

Last April, Brasilia hosted the first Brazil-CARICOM Summit. Most Caribbean States had remained outside the radar of Brazilian diplomacy for far too long and it was about time to remedy such "benign neglect". Not only is the Caribbean an intrinsic part of our region, but also Caribbean countries - including the English-speaking ones - and Brazil have a great deal in common, not least the enormous African contribution to demographics and culture.

Brazil now has permanent diplomatic representation in every single Latin American and Caribbean country. No process of regional integration can be successful without strong bilateral actions, especially when there is a wide perception about asymmetries among the countries involved. Such is certainly the case in South America and might also be true for the whole of Latin America and the Caribbean. Bearing this in mind, Brazil has proposed and carried out many bilateral initiatives - commercial agreements, cooperation projects, financing of infrastructure - with her neighbours. In all these projects and agreements, we tried to exercise solidarity, by voluntarily applying the principle of "less than full reciprocity" that rich countries should observe (but seldom do) in trade negotiations.

11 The Rio Group was formed in 1986 when the Contadora Group and the Support Group - put together to collaborate with a peaceful solution to the conflicts in Central America - merged into a broader group for political concertation. Today, the mechanism reunites almost all countries of Latin America and the Caribbean. 
A recent issue of "The Economist" brought a cover article named "Nobody's backyard". In its American edition, the magazine cover was illustrated with a map of the Western hemisphere turned "upside down" (South on top and North on the bottom), defying conventional geographical wisdom. Curiously, this map reproduces, perhaps unconsciously, the idea of an early $16^{\text {th }}$ century map used as the basis for a tapestry that hangs over the wall of the office of the Brazilian foreign minister in the Itamaraty Palace, in Brasilia. The article rightfully emphasizes the economic changes in Latin America and the Caribbean and how this affected the international status of the region. But the situation depicted by the map also reflects transformations made possible by decisive action in the field of foreign policy.

\section{South-South}

At the crossroads of all the main guidelines of Brazilian foreign policy is the effort to establish closer relations with other developing countries. South-South cooperation is a diplomatic strategy that originates from an authentic desire to exercise solidarity toward poorer countries. At the same time, it helps expand Brazil's participation in world affairs. Cooperation among equals in matters of trade, investment, science and technology and other fields reinforces our stature and strengthens our position in trade, finance and climate negotiations. Last but not least, building coalitions with developing countries is also a way of engaging in the reform of global governance in order to make international institutions fairer and more democratic.

On President Lula's second day in office, I hosted Minister Nkosazana Zuma of South Africa and she raised the need for new mechanisms of coordination among some major countries of the South. Having gone through, in my previous experience as a diplomat and foreign minister, so many failed attempts of establishing such groups, but still recognizing the validity of my colleague's (and, later on, also my friend's) concern, I suggested we should try something relatively simple: a small group - only three countries - one in each continent of the South, all of them vibrant multiethnic, multicultural democracies, with an ever-increasing role in the world: India, South Africa and Brazil. Thus the idea of creating what came to be known as IBSA was born. After consultations conducted by the South African Foreign Minister with our Indian counterpart, the first meeting, at Ministerial level, was convened in Brasilia in June 2003, involving Zuma, Sinha (from India) and myself. The $19^{\text {th }}$ - century three-seat piece of furniture where we sat on together to symbolize the new union still stands as I write this article in the Foreign Minister's office. By now, IBSA has been the object of four Summits, fifteen Foreign Minister meetings; an ever-larger number of Ministerial meetings of sectorial nature and innumerable events involving civil society.

IBSA has also been a pioneering example of South-South cooperation, not only for the benefit of the peoples of India, Brazil and South Africa, but also in 
favour of poorer nations. The IBSA Fund finances development projects in some of the world's poorest countries: Burundi, Cambodia, Guinea-Bissau, Laos, Palestine, Sierra Leone and, most notably, Haiti.

On the margins of the $65^{\text {th }}$ General Assembly, IBSA Ministers held a meeting with Indonesia (on the subject of Palestine) with the presence of the Palestinian Foreign Minister. Curiously, an article written by former Secretary of State Condoleezza Rice before she left office, make specific reference to those four countries - the members of IBSA and Indonesia - as new stakeholders of global stability:

"The importance of strong relations with global players extends to those that are emerging. With those, particularly India and Brazil, the United States has built deeper and broader ties. (...) Today, India and Brazil look outward as never before, secure in their ability to compete and succeed in the global economy. In both countries, national interests are being redefined as Indians and Brazilians realize their direct stake in a democratic, secure, and open international order - and their commensurate responsibilities for strengthening it and defending it against the major transnational challenges of our era. We have a vital interest in the success and prosperity of these and other large multiethnic democracies with global reach, such as Indonesia and South Africa"12

Another example of how Brazil plays her part in this game of "variable geometry" is our strong support for the institutionalisation of the BRIC (Brazil, Russia, India and China) group ${ }^{13}$. These four countries - which combined account for roughly one third of the world's population, $15 \%$ of the global economy and more than half of the economic growth in the last decade - have already shown their weight in the discussions of global economic and political matters - most notably at the Financial G-20.

Last April, Brasilia hosted, on the same day, twin summits of emerging nations: the $4^{\text {th }}$ Summit of Heads of State and Government of IBSA and the $2^{\text {nd }}$ BRIC Summit. Brazil, China, India, Russia and South Africa agreed upon the urgency of reforming global governance. Whereas BRIC can rightfully claim to be the new heavyweight of international relations, the IBSA Forum is perhaps one example of imaginative diplomacy put at the service of building a fairer and more democratic world order.

\section{Africa, Middle East and beyond}

Outside South America, priority has been given to enhancing our relations with Africa. Brazil has the largest African-descendent population outside that

12 RICE, Condoleezza. Rethinking the national interest. Foreign Policy, Volume 84, Number 4, July/August 2008. 13 This new category was first invented by an economist specialized in finance matters, Jim O'Neill of the Goldman Sacks. 
continent. Beyond incidental political and economic gains, the search for closer relations with Africa is guided by historic, demographic and cultural bonds.

African Portuguese-speaking countries are, quite understandably, the ones with whom Brazil has the most enduring, solid and diversified relationships. Back in 1975 Brazil was the very first country to recognize Angola's independence, at a time when the ruling party in Luanda was ill-judged by most of the international community. Such bold gesture granted Brazil a special relationship with that former Portuguese colony that lives on in our days. Progressively, stronger relations were developed with all five "PALOPs"14. The Community of Portuguese-Speaking Countries (or CPLP) - originally idealized by Ambassador José Aparecido de Oliveira following a Summit held in São Luís do Maranhão, Brazil, in 1989, and formally established in 1996 - brought us even closer to those African nations.

Brazil's movement toward the African continent was not limited to the Portuguese-speaking nations. By the end of his second term in office, President Lula will have visited Africa 12 times, including as many as 23 countries. Few, if any, non-African (or even African) leaders can claim such a record. The fact that President Lula was a guest of honour at the $13^{\text {th }}$ African Union Summit held in Sirte, Libya, in July 2009 - upon invitation by the President of the Commission of the African Union - is a testimony to the fact that his commitment to Africa is recognized.

A string of targeted initiatives in technical cooperation with African countries have been set in motion under the coordination of the Brazilian Cooperation Agency. In 2008 the Brazilian State-Institution for agricultural research (Embrapa) opened an office in Accra, Ghana, in order to share its technology, which has tremendously improved the productivity of Brazilian cerrados and may be replicated in the African savannahs. Brazil also maintains a cotton-producing model-farm in Mali, one of the members of the Cotton- 4 group. ${ }^{15}$ In Mozambique, our Government financed the construction of a factory of anti-HIV/AIDS medicaments, which will soon start production. There are units of the Brazilian national industrial training service (Senai, in its acronym in Portuguese) in Angola, Cape Verde, Guinea-Bissau, Mozambique and São Tomé \& Principe. Africa is the destination of as much as $60 \%$ of the Brazilian Cooperation Agency's budget.

As a follow-up to President Lula's attendance to the Sirte Summit, the $1^{\text {st }}$ Brazil-Africa Dialogue on Food Security was organized in Brasilia last May, aiming at combating hunger, alleviating poverty and promoting development of the African continent. The first Brazil-ECOWAS (Economic Community of West African States) Summit took place in the Island of Sal, Cape Verde, in July, with a view to establishing a zone of peace and cooperation in the South Atlantic

14 Countries using Portuguese as an official language on the African continent.

15 Integrated by Benin, Burkina Faso, Chad and Mali, the group fights against European cotton subsidies, which prevent the output of massive cotton-growers from entering the rich countries' markets. 
and promoting business and other forms of cooperation between our countries. Previously, in July 2006, in Salvador, Bahia, we hosted the $2^{\text {nd }}$ Conference of Intellectuals from Africa and the Diaspora, the first of its kind to be organized outside the African continent.

Since 2007, Brazil coordinates the country-specific Guinea-Bissau "configuration" of the Peace-Building Commission (PBC) of the UN. The PBC is a fairly new organ within the UN System, whose creation Brazil supported enthusiastically. It aims at creating and/or strengthening democratic institutions and improving living conditions in societies affected by war or civil conflict. The concept that a sound political environment - where democracy, the rule of law as well as good social practices prevail - is essential to avoid armed conflict is very dear to Brazil. Strengthening peace and democratic institutions in Guinea-Bissau remains a challenging task, to which Brazil is fully committed.

As result of the political priority attributed to the African continent in Brazilian foreign policy, the number of Brazilian resident embassies in Africa has more than doubled, now covering 39 out of the 53 countries. ${ }^{16}$ In spite of the wellknown financial difficulties of most African nations, thirteen countries of that continent decided to open permanent representation in Brasilia since 2003, putting Brasilia among the top capitals in the world in number of African embassies (29).

As a consequence, not only has political dialogue with African countries improved vigorously, but also trade between the two margins of the Atlantic has expanded fivefold ever since - from US\$ 5 billion in 2002 to US\$ 26 billion in 2008. Taken as a single country Africa would appear as Brazil's fourth commercial partner, only behind China, the United States and Argentina, ahead of traditional partners such as Germany and Japan.

Another diplomatic move initiated by Brazil (in association with Nigeria) was the South American-African Summit. When President Olusegun Obasanjo suggested that Brazil should join Africa in a summit similar to those the continent had with countries such as China and India, we felt that not only Brazil, but the whole of South America should meet Africa on summit level. The first South American-African Countries' Summit was held in Abuja, Nigeria. A second one followed in Isla Margarita, Venezuela, in September 2009. A third edition is scheduled to take place in Libya at the end of 2011.

In May 2005 Brazil hosted 34 leaders to the $1^{\text {st }}$ South American-Arab Countries Summit. A second summit was organized in Doha, Qatar, in 2009, and a third one will be held in Lima, Peru, in 2011. The high level contacts between foreign leaders helped to detect business opportunities and find new forms of

16 There are also two Brazilian Consulate-Generals in Africa: one in Lagos, Nigeria, and the other one in Cape Town, South Africa. 
cooperation - such as the combat against desertification. Common cultural projects also sprung from that original impulse, of which the "Amrik" photographic exhibition about the Arab presence in South America, and the construction of bicultural libraries in Algiers and São Paulo are the most visible examples.

Moreover, the bridge established between South Americans and Arabs put the old logic that the countries of the South should be tutored by the North in their international endeavours to test. In a way, both bi-regional mechanisms - ASPA and ASA, as we call them - represented important steps in the long road toward a more pluralistic world order.

Brazilian foreign policy under President Lula has made a genuine drive toward the Middle East. Lula was the first Brazilian Head of State ever to visit the region officially. Before him, Emperor Dom Pedro II took a trip to the Ottoman Empire in the late $19^{\text {th }}$ century, but his was a cultural and religious expedition for personal enlightenment. President Lula went to Syria, Lebanon, United Arab Emirates, Egypt, Algeria, Qatar, Libya and Saudi Arabia. More recently, the Brazilian President was received in Jordan, Israel, Palestine and Iran. He was the first South American leader to attend an Arab League Summit.

The interest is reciprocal: the Secretary-General of the Arab League, Amr Moussa, has been in Brasilia three times since 2003. Aside from their participation in the first "ASPA" Summit, eight Heads of State and Government of Arab countries visited Brazil in the past eight years. Within a period of less than two weeks, in late 2009, Presidents Shimon Peres of Israel, Mahommoud Abbas of Palestine and Mahmmoud Ahmadinejad of Iran all came to Brasilia.

Trade between Brazil and the Arab countries has multiplied threefold since 2003, and reached in 2008 US\$ 20 billion, with rather balanced trade flows. At its August 2010 Summit in San Juan, Argentina, Mercosul signed a free trade agreement with Egypt. As a matter of fact, the only other country outside South America with which Mercosul ever signed such an agreement was Israel. This is not just a coincidence. The latter agreement has recently entered into force. Similar deals are currently being negotiated with Morocco, Jordan and the Gulf Cooperation Council. A process is soon to be launched for FTAs with Syria and Palestine.

This push towards the Middle East was also motivated by the fact that Brazil is home to an estimated 10 to 12 million Arab-descendants - roughly 5\% of our population. We are also proud of the very dynamic Jewish community. Both communities are fully integrated in our society. In fact, the largest populations of Lebanese and Syrian origin outside those countries are in Brazil. Depending on the way they are counted, there are twice as many Lebanese in Brazil as in Lebanon herself. Foreign policy ought to be in touch with the society it represents. As with Africa, Brazilian diplomacy could not ignore such reality.

That Brazil can contribute to the Middle East peace process is not only our view, but also that of countries in the region. As far back as 1993, serving 
as Minister under a previous Government, I had an interview with then Foreign Minister, now President, Shimon Peres, who urged Brazil to be more involved in the Middle East in order to exercise, in his words, a "moderating influence on the Arabs". Whatever the merits (and biases) of such assertion, it shows the Israeli interest in a bigger presence of Brazil in the region. The following year, Brazil was invited by both the Jordanian and the Israeli governments to be present at the ceremony in the Arava Valley, in which the Peace Treaty between the two countries was signed. Brazil was the only country in Latin America and the Caribbean to receive such an honour. It fell to me to represent my country. Our attitudes in the Security Council, over the last twenty years, in issues like Iraq, Libya and, more recently, Syria, Lebanon and Iran, contribute to make it clear that Brazil acts in accordance with her own judgement, even when under strong diplomatic pressure. More recently, as contacts with countries in the Middle East multiplied (with Arab nations, as we have seen, but also with Israel, Turkey and Iran), Brazil became more involved in the questions relating to peace and security in that troubled region.

Brazil is an unyielding defender of an independent Palestine, living in peace with Israel, within the pre-1967 borders with East Jerusalem as its capital. Brazil was invited to the Annapolis Conference in 2007, and was one of the few developing countries outside of the region to attend it. In fact, Brazil, India and South Africa were the only extra-regional, non-Islamic, non-traditional donor countries to receive the original invitation.

During the Israeli attack on Gaza in January 2009, I personally toured the region in order to convey Brazil's message of peace. Brazil also made two substantial contributions, amounting to US\$ 20 million to Palestine to support development in the West Bank and the reconstruction of the Gaza Strip. Along with our IBSA partners, we funded the construction of a sporting facility in Ramallah. We also made resources available for the reconstruction of a hospital in Gaza, when conditions on the ground permit.

In Asia, India and China are already our strategic partners not only in name but in volume of trade and cooperation projects. Brazil and India shoulder each other in the IBSA Forum, in the BRIC and BASIC groups, the twin G-20s, the G-4 (which maintains a close dialogue with South Africa) and in many other multilateral negotiations. Brazil and China too are partners in the BRIC and the twin G-20s. In 2009 China became - for the first time - our main commercial partner, surpassing the United States, who had held that position for almost a century. Relations with Indonesia - a vibrant democracy - have been improving steadfastly. Timor-Leste is a country with which Brazil has an affectionate and cultural relationship, due both to the fact that she is a Portuguese-speaking country and to her struggle for independence, which Brazil strongly supported in the UN. Besides our traditional relations with Japan and the majority of the members of the Association of Southeast Asian Nations (ASEAN), we opened 
(or will soon open) embassies in Afghanistan, Armenia, Azerbaijan, Bangladesh, Kazakhstan, Myanmar, Nepal, North Korea and Sri Lanka; and consulates in Canton, Hamamatsu, Mumbai and Shanghai. In 2007 Brasilia hosted the first Forum for East Asia-Latin America Cooperation (FEALAC) meant to improve business and political contacts across the two regions. At that occasion, we launched the seeds of a bi-regional association between Mercosul and the ASEAN.

Countries like Portugal, Spain, Italy, the United Kingdom, Sweden - to quote a few - are longstanding partners of Brazil. With these and other Western European countries, we have been strengthening our bonds. With some of them we formally established strategic relationships (Sweden and Spain are two examples). Recently I toured several Central and Eastern European countries, including quite a few where a Brazilian Foreign Minister had never set foot on, such as Estonia, Serbia, Bosnia \& Herzegovina, Bulgaria and Romenia.

Brazil is one of the few countries to have established a Strategic Partnership with the European Union. Among other benefits, this may help to pave the way for the establishment of a Mercosur-EU Association Treaty. In addition to the commercial opportunities, the political dialogue between leaders has permitted greater coordination and, some times, even joint initiatives in areas like energy, climate, and the treatment of the financial crisis.

With France, not only did Brazil establish a fruitful Strategic Partnership in 2007: we also gave muscle to it by setting in motion a number of bilateral initiatives. The Year of Brazil in France (2005) and the Year of France in Brazil (2009) were successful in bringing the French and the Brazilian peoples closer together. According to French data, Brazil, which has important defence needs, mainly in the Amazon and on her economic zone in the Atlantic (where huge reserves of oil have been found), has become the number one market for the French defence industry.

The dialogue with the United States has seldom been so intense. We tend to emphasize our commonalities even when we disagree on specific subjects. This has been instrumental in defusing tensions in situations such as the Venezuela crisis in 2003/2004 or in reconstruction efforts in Haiti. It also helped ensure a smooth course for the resolution that revoked Cuba's suspension from the Organisation of American States (OAS) in May 2010.

Aside from the shared values of two great multiethnic democracies of the Western hemisphere, there is a wide positive agenda set forth by our governments. We recently signed Memoranda of Understanding on Biofuels, on Combating Racial Discrimination, on Promoting of Gender Equality, on Climate Change and on Trilateral Cooperation to the benefit of Central American and Caribbean countries, as well as African ones. Earlier this year, during Secretary Hillary 
Clinton's visit to Brasilia, a Global Partnership Dialogue was established between Itamaraty and the Department of State.

Brazil and the US are the two largest economies of the hemisphere. Recent data show Brazil as the country with which the US has the largest trade surplus, a dubious honour from our point of view, but an indicator of the intensity of the bilateral relations. Both our countries were also very active in upgrading the Financial G-20 as the prime forum for macroeconomic coordination. We have been strong partners - even if not always agreeing on every single point - on trade negotiations and climate change discussions. In the hemisphere and beyond, Brazil and the US have a great deal to gain from a strong relationship.

Even though the relative weight of the United States among Brazil's trade partners has been dropping in the last few years, in absolute numbers our commercial relations have actually doubled. The US remains one of our leading business partners, but is now rivalled by China and, more recently, by Argentina in strictly commercial terms (of course investment flows from US to Brazil are not challenged by our Southern neighbour). This shows that Brazil diversified our trade without harm to the old and traditional relations.

\section{Human rights}

Brazil's commitment to the promotion of human rights is unwavering both within our borders and on a global scale. Brazil sees human rights being profoundly related to democracy, peace and development. The promotion of human rights is at the heart of Brazilian foreign policy, as illustrated by our attitude of solidarity and non-indifference toward many of the most vulnerable peoples on the planet.

In multilateral fora, Brazil favours a non-selective and objective treatment of human rights, one that avoids politicisation or bias. Every single country - the rich and the poor, the powerful and the weak, either in Africa or in Europe - should be subject to the same methods of scrutiny, without double standards. That is why Brazil was one of the most enthusiastic proponents of the mechanism known as the Universal Periodic Review (UPR), which gives universal, undifferentiated treatment to every single country. In Brazil's view, although subject to further improvements, this mechanism has been achieving remarkable results since its establishment in 2008.

As I had the chance to state before the $65^{\text {th }} \mathrm{UN}$ General Assembly, more often than not, the exercise of human rights is more effectively ensured by dialogue and cooperation than by arrogant attitudes derived from self-declared moral superiority. A harsh condemnation of this or that country in Geneva or New York, based on a self-ascribed position of high moral ground, does little to ameliorate the situation of those perishing in the field. Engaging in real dialogue with the authorities with the actual means to make peoples' lives less miserable 
is - as a rule - more productive for improving human rights then a resounding speech in the Human Rights Council.

In this field, as in many others, preaching by example achieve far greater results than rhetoric. Brazil wishes to give a real contribution to those suffering from human rights violations. Apart from many other actions of humanitarian nature we have undertaken in the recent past, we have just decided to make an important financial contribution to the High Commissioner of Human Rights specifically directed to a project that seeks to alleviate the plight of women who have been victims of sexual violence in the Democratic Republic of Congo.

\section{Conclusion}

In the last eight years, Brazil's role in the world has undeniably attained new heights. Our voice is heard with greater attention not because we scream louder, but because we are more respected. That has a lot to do with the growth of our economy, the vibrancy of our democracy and the example of our social policies. But some of the success can also be credited to our foreign policy.

From the outset, empowered with the mandate for change received in his election, President Lula decided to follow a foreign policy that was both active and bold. With the benefit of hindsight, it is also possible to say that President Lula's foreign policy was also creative - or "imaginative", as the professor interviewed by "Le Monde" said.

Foreign policy has also been a motive for the Brazilian people's renewed sense of self-esteem. As we approach the end of President Lula's Administration, a great number of articles in the international press have been focusing on what our diplomacy has accomplished over the last eight years. Indeed, having been a career diplomat for most of my life and serving as Foreign Minister for the second time, I can say, with all certainty, that in no previous period of our History, Brazil's role in the world has been the object of so much interest and, I dare say - at least in some cases - admiration.

A recent survey carried out by the Pew Research Institute attested that 78\% of Brazilians support the way our foreign policy has been conducted. Even more impressive, Pew Research detected that $77 \%$ of Brazilians believe their country already is or will eventually become a "superpower". Granting that nobody knows very clearly what being a "superpower" means, there is no doubt that a profound transformation in the national collective psychology is underway.

This is a far-cry from the self-demeaning mindset that was so common in Brazil. In the late 50s, the famous journalist, playwright and often football commentator Nelson Rodrigues coined the expression "stray dog complex" to describe the defeatist mentality that resulted from the frustration with the Brazilian national team almost among the finalists, but never a champion. The victories in the World Cups of 1958, 1962 and 1970 (and, further on, 1994 and 2002) totally 
dissipated that feeling. But it subsisted in other fields of Brazilian life - politics included. Twenty-one years of dictatorship, decades of hyperinflation, the dubious record of being one the countries with the highest degree of social inequality, all contributed to this complex of inferiority, which is finally being overcome.

In the 1911 novel "The Sad End of Policarpo Quaresma" - commonly translated in the Anglo-Saxon world as "The Patriot" - the great Brazilian writer Lima Barreto used his leading character's voice to say that "the great fatherland of the [Southern] Cross", i.e. Brazil, "required nothing more than time" to become a great power - in his words, "to surpass England". According to Quaresma, "experiencing every climate, (...) every fruit, every useful animal and mineral, the finest arable land and the bravest, gentlest, most hospitable and most intelligent people in the world - what more could it want? Time and a little originality."

In the last eight years, the world changed and Brazil changed. One of the merits of President Lula's foreign policy was to foresee and understand such changes - and sometimes even anticipate them. Whatever criticism one may raise (and it is good that it should be this way, since all human activity is subject to criticism), that in itself is no small achievement.

Received October 25, 2010 Accepted November 11, 2010

\begin{abstract}
Foreign Minister of Brazil since 2003, Ambassador Celso Amorim outlines the main guidelines and accomplishments of Brazil's foreign policy under President Luiz Inácio Lula da Silva. The article provides a full-fledged, although not exhaustive, narrative of a number of diplomatic initiatives championed by Brazil over the last eight years: from the gathering of the group of developing countries in a World Trade Organization (WTO) meeting in Cancun to the negotiations that led to the Declaration of Tehran, as well as the challenges the country has been facing as its international weight grows.
\end{abstract}

\title{
Resumo
}

Ministro das Relações Exteriores do Brasil desde 2003, o Embaixador Celso Amorim descreve neste artigo as principais orientações e realizações de política externa no governo do presidente Luiz Inácio Lula da Silva. O artigo apresenta uma narrativa completa, embora não exaustiva, de uma série de iniciativas diplomáticas defendidas pelo Brasil nos últimos oito anos: desde o agrupamento de países em desenvolvimento na conferência da Organização Mundial do Comércio (OMC) em Cancún até as negociações que levaram à Declaração de Teerã, bem como os desafios que o país vem enfrentando na medida em que a sua visibilidade internacional aumenta.

Key-words: Brazilian Foreign Policy; Lula's administration.

Palavras-chave: Política Externa Brasileira; Governo Lula. 